REVISTA de

PEDAGOGIE

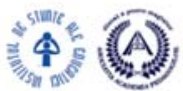

http://revped.ise.ro

Print ISSN 0034-8678; Online ISSN: 2559 - 639X

\title{
UKRAINIAN EXPERIENCE OF ENHANCING SECONDARY SCHOOL PUPILS' FINANCIAL LITERACY AT MATHEMATICS LESSONS
}

\author{
EXPERIENTTA UCRAINEANĂ PENTRU OPTIMIZAREA ÎNVĂŢĂMÂNTULUI \\ SECUNDAR: ALFABETIZAREA FINANCIARĂ ÎN CADRUL ORELOR DE \\ MATEMATICĂ
}

\section{Nataliia VASYLIUK}

$$
\begin{gathered}
\text { Journal of Pedagogy, } 2017 \text { (2), } 85 \text { - } 95 \\
\text { https://doi.org/10.26755/RevPed/2017.2/85 }
\end{gathered}
$$

The online version of this article can be found at: http://revped.ise.ro/category/2017-en/

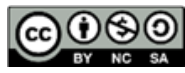

This work is licensed under the Creative Commons Attribution-NonCommercial-ShareAlike 4.0 International License. To view a copy of this license, visit http://creativecommons.org/licenses/by-nc-sa/4.0/ or send a letter to Creative Commons, PO Box 1866 , Mountain View, CA 94042, USA.

Published by:

\section{INSTITUTUL DE ȘTIINȚE ALE EDUCAȚIEI}

http://www.ise.ro/

Further information about Revista de Pedagogie - Journal of Pedagogy can be found at:

Editorial Policy: http://revped.ise.ro/editorial-policy/

Author Guidelines: http://revped.ise.ro/the-writer-guide-2/ 


\title{
UKRAINIAN EXPERIENCE OF ENHANCING SECONDARY SCHOOL PUPILS' FINANCIAL LITERACY AT MATHEMATICS LESSONS
}

Nataliia VASYLIUK*

\begin{abstract}
The article covers the role of financial literacy in the country's economic growth, reveals the essence of the notion and significance of financial literacy, highlights the main results of studies that determine the level of financial literacy of the population of Romania and Ukraine. The main steps to improve the level of financial literacy of the citizens of both countries are listed. The Ukrainian experience of developing financial literacy of high school students during mathematics lessons is underscored. The author suggests the recommendations and certain examples of tasks for raising the level of financial literacy of high school pupils in the process of teaching mathematics.
\end{abstract}

Keywords: financial literacy; lessons of mathematics; mathematics training; problems of financial content.

\section{Rezumat}

Articolul se referă la rolul alfabetizării financiare în creşterea economică a ării, relevă esen a acestui concept şi semnifica ia sa, subliniază principalele rezultate ale studiilor, care determină nivelul de alfabetizare financiară a popula iei din România şi din Ucraina. Totodată, sunt enumerate principalele etape pentru îmbunătă irea nivelului de educa ie financiară a cetă enilor din cele două ări. Este eviden iată experien a ucraineană de formare a alfabetizării financiare a elevilor în cadrul lec iilor de matematică. Autoarea propune recomandări şi exemple de sarcini de lucru pentru creşterea nivelului de alfabetizare financiară a elevilor de liceu, în procesul de învă are a matematicii. Cuvinte-cheie: alfabetizare financiară; lec ii de matematică; pregătire matematică; probleme cu con inut financiar.

\footnotetext{
* Postgraduate student at the Institute of Pedagogy of the National Academy of Education Sciences of Ukraine Kyiv, Ukraine; natalimarynina@gmail.com
} 


\section{Introduction}

An inevitable attribute of modern successful people is financial literacy, which enables them to manage their own and family finances, and be successful in the financial services market. Financial literacy plays a crucial role in the country's economic growth and higher incomes. After all, society achieves the greatest economic success, when citizens of the country have the proper knowledge and skills of making responsible and conscious decisions in the financial sphere.

Today, financial literacy is one of the most important European competencies of education in Europe. In 2012, it was assessed in the international comparative research conducted by PISA and is the research subject of scientists from different countries of the world. Annamaria Lusardi notes that "financial literacy is an essential tool for anyone who wants to be able to succeed in today's society, make sound financial decisions, and ultimately be a good citizen" (Council for Economic Education, 2011).

The term financial literacy was firstly used in 1997 in the research The Jump \$tart Survey of Financial Literacy among High School Students provided by the Jump \$tart Coalition for Personal Financial Literacy. They interpreted it as "the ability to use knowledge and skills to manage one's financial resources effectively for lifetime financial security".

The OECD publication (2014) defines financial literacy as "knowledge and understanding of financial concepts and risks, and the skills, motivation and confidence to apply such knowledge and understanding, in order to make effective decisions across a range of financial contexts, to improve the financial wellbeing of individuals and society, and to enable participation in economic life".

The term financial literacy has a large number of definitions, but most of them contain the same components, namely: the availability of knowledge and skills for effective use and management of finances.

\section{Results of the research on the population's financial literacy}

In 2014, Standard \& Poor's, an international rating agency jointly with Gallup, the World Bank and the Global Financial Literacy Excellence Center (GFLEC) at the George Washington University, conducted a research, based on a survey and then published a report on the web site of McGraw Hill Financial (a maternal company of Standard \& Poor's). 
The Global FinLit Survey, explores the literacy questions that measure four fundamental concepts for financial decision-making - basic numeracy, interest aggregation, inflation, and risk diversification.

The research was conducted in 143 countries all over the world. Ukraine was ranked the 45 th place in the overall survey score (40\% of the adult population is financially literate). The indicated percentages testify to the low level of financial literacy of Ukrainian population.

In September 2010, a financial literacy research was conducted in Ukraine in the project of the US Agency for International Development, "Financial Sector Development" (FINREP). More than 2000 respondents aged 20-60 were asked 64 questions that concerned personal finances and consumer rights protection. Urban respondents from all regions of Ukraine took part in the poll. To find out the results, a random sample method and a personal interview were applied.

The research aim was the following:

- to determine the level of financial literacy of the population of Ukraine (through self-assessment and answers to test financial questions);

- to find out models of financial behaviour of the population regarding family budget management, savings as well as debt and loan management;

- to determine the types of financial services mostly used by the population of Ukraine;

- to find out the level of awareness of the population of Ukraine about the protection of consumers' rights in financial services;

- to identify any deviation from financial literacy and awareness about the protection of financial services consumers based on regional, age and gender features.

According to the results of the research, over $60 \%$ of respondents consider themselves financially literate $(22 \%$ - "good" or "excellent", $41 \%$ "satisfactory"). However, only $22 \%$ of respondents were able to give 5 or 6 correct answers to 7 mathematical questions. Without them, it is impossible to manage one's own finances. $51 \%$ of the respondents were able to answer correctly to not more than three of the questions asked in the questionnaire. It is also found that the most common financial services for the Ukrainian consumer are:

- utilities payments in a bank (78\%);

- usage of a bank account and a plastic card $(61 \%)$;

- payment by terminals of payment systems (38\%);

- currency exchange (31\%). 
Almost $30 \%$ of respondents have debts (they took a loan), and about $20 \%$ of respondents use the money transfer service through the bank. The fact that only $11 \%$ of the population has a savings deposit in the bank shows that Ukrainians have no reason to make savings and there is a high degree of distrust to financial institutions.

Therefore, the results of the research on the level of financial literacy of the population of Ukraine show that "a significant number of people aged 20-60 are not well aware of what is a credit, mortgage, insurance, variable interest rates, investment funds, stocks or bonds. Most of Ukrainians cannot correctly answer the usual mathematical questions that deal with managing their own finances. Nowadays it is a common. Indeed, according to the research, even in developed economies, the level of financial literacy of most people remains low. Instead, in Ukraine, this problem is further complicated by the insufficient level of knowledge of consumer rights in the financial services area" (Bond, 2010).

\section{Measures to enhance financial literacy}

The problem of low level of financial literacy of the population is currently urgent. The governments of developed countries invest heavily in raising the level of financial literacy of the population. At present, significantly more countries are convinced of the importance of developing financial literacy for school-age children, and therefore they are implementing national strategies in the area of financial education in order to increase financial literacy of the population. Particular attention is focused on the younger generation, as it is a potential consumer of financial services and a user of banking services.

\subsection{Increasing the level of financial literacy of the population of Ukraine}

At present, Ukraine is taking the first steps to increase financial literacy of the population, in particular, school-age children. Governmental agencies are putting certain efforts to implement a national strategy to increase financial literacy of the population through the development and implementation of initiatives: "NBU Action Plan to raise the level of financial literacy of the population of Ukraine" (01.08.2013); Order of the Ministry of Education and Science of Ukraine of March 24, 2016 No. 324, "Scientific and methodological principles of financial literacy introduction in the educational process of educational institutions" for 2012-2019.

In particular, from September 2012 to May 2013 in 86 state schools, with the support and in cooperation with the National Bank of Ukraine, the University of Banking of the National Bank of Ukraine and the Ministry of Education and Science of Ukraine, an experimental All-Ukrainian course "Financial literacy" was introduced. It attracted 3,400 pupils aged from 15 to 16 from 18 regions 
of the country. The Financial Literacy course is designed for a full academic year and consists of four blocks: Money and Finance, Savings and Investments, Borrowing, Insurance and Own Budget.

Currently, the Financial Literacy course was developed and introduced for the high school; its main purpose was to introduce modern financial products and services for pupils, develop the skills of using such products, as well as the skills of their own financial planning for the future.

At the current stage of the education development in Ukraine, introduction of a competent approach to training in the comprehensive educational institutions is considered; that is, the educational process is directed at achieving results. General subject and core competences are hierarchically subordinate to them. In February 2017, an activity organized under the EdEra's social platform for comprehensive secondary education (see https://www.ed-era.com/mon59/) was the forum to discuss the topic. The participants were scholars, educators, experts and parents. The mainstream school programs have integrated crosscutting lines, which are aimed at forming pupils' key competencies in pupils. Four cross-cutting lines that are covered in the study of all school subjects are offered. They are the following:

- Health and Safety;

- Civic Liability;

- Entrepreneurship and Financial Literacy;

- Environmental Safety and Sustainable Development.

According to the curriculum for Math Grades 5-9 in cross-cutting lines and their application, it should be notified that the cross-cutting line "Entrepreneurship and Financial literacy" aims at developing leadership initiatives, the ability to operate in a rapidly changing environment successfully, providing pupils with a better understanding of the practical aspects of financial issues (saving, investing, borrowing, insurance, lending, etc.).

The proposed cross-cutting line involves solving practical tasks related to planning of economic activity and real assessment of one's own opportunities, drawing up a family budget, and creating a saving attitude to natural resources. It is implemented in the process of studying interest calculations, equations and functions.

\subsubsection{Implementation of financial literacy elements in the school mathematics course}

The content of Mathematics course has a great potential for the development of financial literacy in the process of its study; it will facilitate the formation of 
pupils' knowledge, skills and abilities of using mathematical knowledge in the financial sphere of practical activity, highlights the inter-curricula links and the role of mathematics in the theory of finance, forms a cognitive interest in studying mathematics, improves the quality of mathematical training of pupils.

To form financial awareness and develop financial literacy it is desirable to offer pupils the tasks related to financial transactions, the value of goods and services, charity, taxes, etc. For modern pupils, the tasks of distribution of finance in the family, the securities market, taxes and their distribution, rules for accrual of pensions, banking services, insurance and risks will be interesting.

It is necessary to extend the system of tasks of the secondary school mathematics course by the tasks of financial content. It is also advisable to involve pupils in drafting financial tasks.

\subsubsection{Mathematical tasks of financial content}

In the $5^{\text {th }}$ grade, it is expedient to use the tasks which require determining which cost of purchases will be greater, in which the shop it is cheaper to buy a list of some products, finding out if there is enough money to make a certain purchase. In order to stimulate pupils to project activities, it is advisable to compare them with the costs and income of their family during the past month.

For the pupils of $5-6^{\text {th }}$ forms, it is necessary to offer tasks related to the currencies exchange. Knowledge and skills related to currency exchange will enhance pupils' interest in math studies and the application orientation of the course. The task of purchasing goods in instalments, discounts and promotions for goods could also be interesting. From the $6^{\text {th }}$ form, pupils can be offered tasks on deposits and loans.

For example, let's consider the didactic game "Souvenirs". On a multimedia banner, children are presented images of souvenirs, which are usually brought by tourists for their relatives from a particular country as well as their price. The exchange rate is also reported.

Tasks that a teacher can offer:

- Calculate the price of each souvenir in national currency.

- What will be the purchase price (in lei/RON) of all eatables of both countries?

- How much money do you need to buy all the souvenirs?

- What souvenirs and how many of them can you buy if you have 20 euro left? How much will it cost in lei/RON? 
- If you have planned that you could spend no more than 100 lei/RON on souvenirs, which of the souvenirs could you buy?

\section{Souvenirs Tirom Romania}

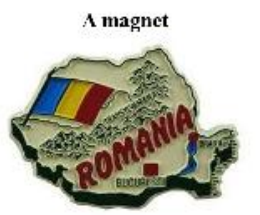

$2 \mathrm{EUR}=$ RON

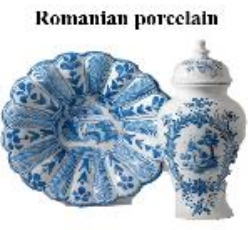

$31 \mathrm{EUR}=$ RON

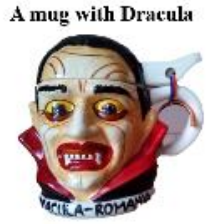

S ELR = KON

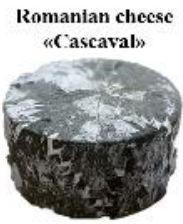

$19 \mathrm{EUR}=$ RON

A plate with Dracula castle

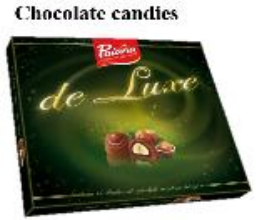

GELR $=$

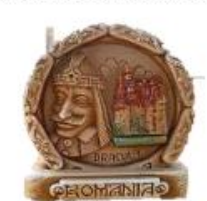

$16 \mathrm{EUR}=$
A unique vase

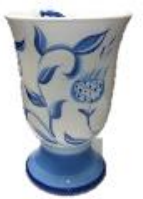

$23 \mathrm{ELR}=$ RON
A basket from a willowed

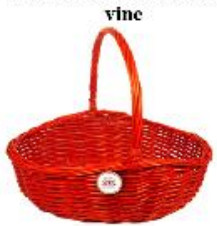

$11 \mathrm{ELR}=$ RON
Souvenirs T'rom Vkraine

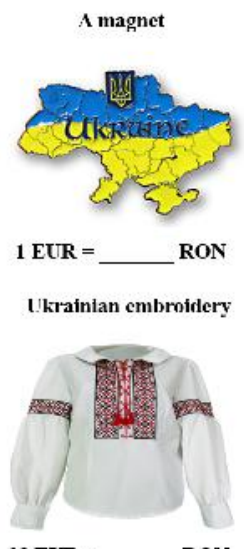

$38 \mathrm{EUR}=$ RON

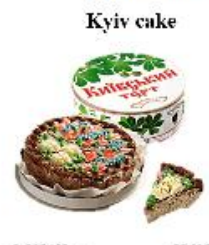

$6 \mathrm{ELR}=$ RON

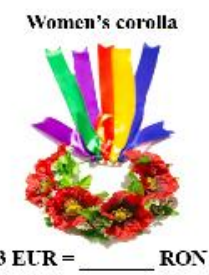

A I-shirt

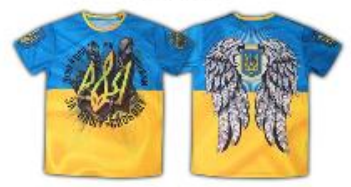

$11 \mathrm{EUR}=$ RON
The plate with the city of Lviv

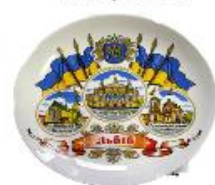

8 EUR = RON

\section{Figure 1. Picture of souvenirs}

In the $7^{\text {th }}$ form, pupils should be offered to solve the plot tasks for using their own and family finances. Particular importance is granted to solving the tasks for the study of functions and constructs of graphs relating to different dependencies. 
Example. Make a function that determines the cost of traveling by your own car depending on the journey distance if your car consumes 7.5 litres of petrol per $100 \mathrm{~km}$. How much money do you need to buy petrol for a car for a trip from Bucharest to Brasov? Find out the price of a train ticket and compare costs in both cases. Under which conditions can a car travel be more economical?

The solution of this task is possible only if we know the distance from Bucharest to Brasov, the price of gasoline per 1 litre and the price of a train ticket from one city to another. These are the questions that must be often answered by adults in everyday life.

In the $8^{\text {th }}$ form, pupils will be interested in the plot tasks that cover the usage of interconnections of economic phenomena, types and calculations of taxes, the implementation of payments, the cost of goods, expenses and revenues, etc.

In the $9^{\text {th }}$ form, pupils are encouraged to use the plot tasks for calculating and analysing the financial capacity of the family, calculating the amount of taxes paid, making decisions on personal and collective financial issues etc. In the $9^{\text {th }}$ grade, it is also useful to offer pupils the task of processing graphs and diagrams, analysis of the situation or statistical data. In our opinion, the task of processing the schedule, "Euro Course" could be also beneficial for pupils.

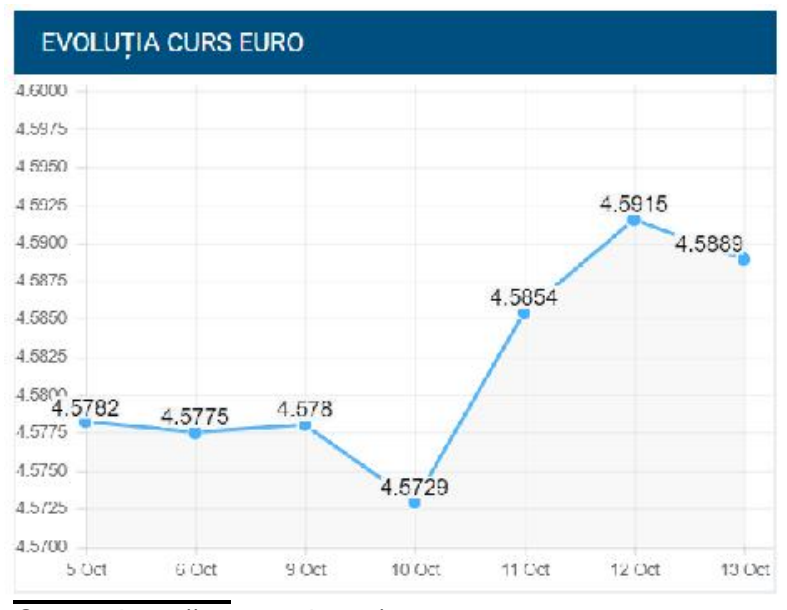

Source: https://www.cursbnr.ro/

Figure 1. Euro exchange rate 
Tasks that the teacher can offer are the following:

- What period was the schedule built up for?

- What is the biggest value for the euro recorded for this gap? What's the least?

- Draw a chart where the exchange rate is fixed for each of the specified days.

- Find the average euro for a certain period.

- Under the chart, construct the corresponding column diagram.

\subsection{Increasing the level of financial literacy of the Romanian young people}

In order to increase the financial literacy of young people, a number of particular measures have been taken: the authorities, as well as various financial institutions, have launched various educational programs for the public.

Junior Achievement România is a non-profit organization of entrepreneurship, financial education and professional guidance for different age groups that runs free international programs, from elementary school to university. Also in Bucharest, more than 30 public and private schools, Banca Transilvania and Ken Academy initiated a financial and entrepreneurial education program for 1-8 year olds.

The Romanian Commercial Bank launched a campaign through the first Financial Dialogue Center, offering free consultations to the people. Besides, in partnership with the Education Association, the Ministry of Education and Infomedia Romania, the program "From Game to Financial Education" was implemented for 23,000 preschool children in seven constituencies Bucharest, Sibiu, Dolj, Constan a, Cluj, Timiş and laşi. As a result of the program, children received free teaching materials (manuals, software), and 7,000 teachers learned how to give lessons of financial education in kindergartens.

\section{Conclusions}

At present, Romania and Ukraine have taken significant steps to improve the financial literacy of their citizens, especially for school-age children. National strategies for increasing financial literacy of the population are being developed and implemented, and various educational programs for the public are launched. Particular attention is paid to school-age children as they are young and active consumers of financial services and users of banking services. That is why it is necessary to start the process of formation of knowledge and skills of correct use of money at school age. 
Significant potential for formation of pupils' financial literacy is laid in the discipline "Mathematics". The solving of financial-oriented tasks during the study of mathematics, promotes the development of skills and abilities of pupils to apply mathematical knowledge in practical activities and to raise awareness of the youth in related to taxation and fiscal activities of the state.

The distribution and popularization of elementary financial knowledge enables the disclosure of interdisciplinary connections and the role of mathematics in the theory of finance, in the peoples' and the state life, the development of pupils' cognitive interest, and the improvement of the quality of their mathematical education.

\section{REFERENCES}

Bond R., Kutsenko O., \& Lozynska N. (2010). Financial Literacy and Awareness in Ukraine: Facts and Conclusions. FINREP, Financial Sector Development Project.

Council for Economic Education (2011). Survey of the State's: Economic and personal finance education in our nation's schools. Retrieved from http://councilforeconed.org/policy-and-advocacy/survey-of-the-states/.

Educational program for comprehensive educational institutions. Mathematics

5-9 classes (with changes approved by the order of the Ministry of Education and Science a 804 of 07. 06. 2017). Retrieved from

https://www.ed-era.com/img/books/mon59/programs/5.programa-zmatematiki.pdf.

Klapper L., Lusardi A., \& van Oudheusen, P. (2015). Financial Literacy around the World: Insights from the Standard \& Poor's Ratings Services Global Financial Literacy Survey. Working Paper, GFLEC.

Mandell, L. (1997). Personal finance survey of high school seniors. Washington, D.C.: Jump \$tart Coalition for Personal Financial Literacy.

OECD PISA (2014). 2012 Results: Students and Money (Volume VI) Financial Literacy Skills for the 21st Century. Paris: OECD Publishing.

*** Order of the Ministry of Education and Science of Ukraine dated March 24, 2016 no 324 "Scientific and methodological principles of introduction of financial literacy in the educational process of educational institutions" for 2012-2019. Retrieved from

https://imzo.gov.ua/.../nakaz-mon-vid-24-03-2016-324-pro-rozshirennya-bazidlya-p.

*** "NBU Action Plan on raising the level of financial literacy of the population of Ukraine" dated August 1, 2013. Retrieved from http://bank.gov.ua/control/uk. 


\begin{tabular}{|c|c|}
\hline $\begin{array}{l}\text { The online version of this article can be found } \\
\text { at: http://revped.ise.ro/category/2017-en/ }\end{array}$ & $\begin{array}{l}\text { Versiunea online a acestui articol poate fi găsită } \\
\text { la: http://revped.ise.ro/category/2017-ro/ }\end{array}$ \\
\hline (c) (1) (9) & (c) () (9) \\
\hline $\begin{array}{l}\text { This work is licensed under the Creative } \\
\text { Commons Attribution-NonCommercial- } \\
\text { ShareAlike } 4.0 \text { International License. }\end{array}$ & $\begin{array}{l}\text { Această operă este pusă la dispozi ie sub } \\
\text { licen a Creative Commons Attribution- } \\
\text { NonCommercial-ShareAlike } 4.0 \text { International. }\end{array}$ \\
\hline $\begin{array}{c}\text { To view a copy of this license, visit } \\
\text { http://creativecommons.org/licenses/by-nc- } \\
\text { sa/4.0/ or send a letter to Creative Commons, } \\
\text { PO Box 1866, Mountain View, CA } 94042 \text {, } \\
\text { USA. }\end{array}$ & $\begin{array}{c}\text { Pentru a vedea o copie a acestei licen e, vizita } i \\
\text { http://creativecommons.org/licenses/by-nc- } \\
\text { sa/4.0/ sau trimite i o scrisoare către Creative } \\
\text { Commons, PO Box 1866, Mountain View, } \\
\text { CA 94042, SUA. }\end{array}$ \\
\hline
\end{tabular}

